\title{
Amendments Concerning the Hungarian Legal Regulation of the Fiduciary Asset Management (Trust)
}

\author{
BALÁZS BoDZÁSI*
}

\begin{abstract}
The institution of fiduciary asset management (trust) has been introduced into the Hungarian civil law by the Civil Code of 2013. The Hungarian regulation may be considered as a high standard - even in the international context. Its main advantage is its adaptability. However, after the entry into force of the Civil Code, many questions were addressed during the application that the legislature had to answer. The amendments of 2017 were adopted to strengthen the protective function of the fiduciary asset management regarding the trust property but on the other hand, the relationship between this new legal institution and the law of succession has also needed to be clarified. The purpose of the legislation through the amendments was clearly to facilitate an operable asset management construction that attracts Hungarian and foreign settlors as well.
\end{abstract}

Keywords: separation of assets, protection of trust property, principle of reasonable commercial practices, ownership concerning the fiduciary asset management relationship, right to recover the assets

\section{DIFFERENT FORMS OF ASSET MANAGEMENT IN THE HUNGARIAN LAW}

There are different forms of asset management in the Hungarian law; the vast majority are legal constructions intended for the management of assets owned by other persons. One part of these constructions relate to the management of assets by the state/local government while another part thereof can be applied when safekeeping and accumulating private assets. ${ }^{1}$

The construction of trusteeship was already known in the Hungarian law before the political transition. It was defined as a specific right in rem which arouse in close relation to the state property. The ownership of state assets may not be transferred; however trusteeship may be created on them. Therefore, trusteeship functioned as a quasi ownership (right in another person's thing). ${ }^{2}$ This kind of trusteeship of property law nature is still known in respect of the state/local government properties. $^{3}$

With regard to the management of private assets, the management of assets by the guardian or custodian should be highlighted. ${ }^{4}$ The respective laws are still quite incomplete and in this respect section 2:36 (1) Act V of 2013 on the Civil Code (hereinafter the Civil Code) states that the guardian authority shall exercise supervision of the activities of custodians. Pursuant to subsection (3) of the above section of the Civil Code, the persons placed under custodianship shall be entitled to have access to records on the custodians' activities and also on their own assets and to make copies of such records. Therefore, the persons under custodianship may have access to the documentation on their own assets

* Head of Department of Economic Law at the Corvinus University of Budapest (Hungary). E-mail: balazs.bodzasi@uni-corvinus.hu. The study was funded by the Pallas Athéné Domus Sapientiae Foundation in the framework of the PADS Leader Research Program.

${ }^{1}$ Csehi (2015a) 95-132 with respect to the different forms of asset management.

2 Csizmazia and Sándor (2002) 21-22.

3 Csehi (2015b) 9-52 with respect to the historical background of asset management.

${ }^{4}$ In respect of the asset management by the guardian, see: Csehi (2015a) 128. 
made by the custodian and the guardianship authority and may make copies of such documentation. Section 2:37 of the Civil Code adds to these the custodian's obligation to give account. The obligation to give account shall apply to the management of assets by the custodian.

The Author shares the academic opinion which states that though fiduciary asset management may not replace the institutions of guardianship and custodianship, it may be a suitable legal construction to complete them. By this way double protection can be established for the management of assets owned by persons under guardianship (custodianship). ${ }^{5}$

Before the entry into force of the Civil Code on 15 March 2014, the Hungarian civil law did not regulate the contractual construction of asset management. ${ }^{6}$ Upon the principle of freedom of contract, the parties had the possibility to enter into such contracts but they usually applied other constructions of contracts due to the high transactions costs. ${ }^{7}$ Generally they used the regulations governing personal service contracts but this was not an appropriate solution. For this reason, during the codification of the Civil Code, it was concluded that the new code would regulate fiduciary asset management as a specific contract.

\section{THE SPECIFIC FEATURES OF THE HUNGARIAN LEGAL REGULATION OF FIDUCIARY ASSET MANAGEMENT}

The type of contract with the name of fiduciary asset management in the Civil Code may be compared mostly to the Anglo-Saxon institution of trust. ${ }^{8}$ The Hungarian regulation may be considered as high standard even in the international context and its main advantage is its adaptability.

Despite being regulated by the Civil Code among the specific contracts, fiduciary asset management is not only a contract but rather a specific legal relationship. Though the asset entrusted to the fiduciary is not an independent legal person, the fiduciary asset management is more than just a contract. This is also proven, among others, by the fact that the fiduciary asset management as a legal relationship may be established not only by contract but by a unilateral act e.g., under a will. In addition, the legal relationship may remain even after the termination of the contract or the unilateral statement establishing that legal relationship. This is also reflected by section 6:326 (5) of the Civil Code which says that fiduciary asset management shall not be terminated upon the death or dissolution of the settlors, the trustee or the beneficiary. Furthermore, the wording of the provisions of the Civil Code also mainly uses the expressions 'fiduciary asset management' or 'the fiduciary asset management relationship' instead of 'fiduciary asset management contract' e.g., section $6: 326$ of the Civil Code.

In this special tripartite legal relationship, the separated (managed) assets have a key role. This is also reflected by the provisions concerning the separation of assets and the

5 B. Szabó et al. (2014) 33.

${ }^{6} \mathrm{~A}$ form of asset management completely different from this is establishing a legal person for asset management Mainly foundations may be created for the purpose of asset management but a business association or an investment fund may also be created for this purpose.

${ }^{7}$ For more details, see Menyhárd (2017) 37.

8 The German Treuhand is much more different from the Hungarian fiduciary asset management than the Anglo-Saxon trust. 
protection of assets separated. The trust property is separated from the trustee's own assets and from other trust properties managed by them. The trustee is obliged to keep separate records of such assets; the separation of assets is governed by section 6:312 of the Civil Code). In respect of the protection of trust property, section 6:313 (1) stipulates that the trustee's spouse and cohabitant and personal creditors and creditors of other trust properties by the trustee shall not lay claims to any part of the trust property. The trust property shall not be included in the trustee's estate. ${ }^{9}$

In addition, it is important to stress out the enhanced requirements for the fiduciary. In this respect, section 6:317 (2) of the Civil Code provides that under the principle of reasonable commercial practices, the trustee shall have the obligation to protect the managed assets from foreseeable risks. ${ }^{10}$ It is important to note that this section does not set the principle of reasonable commercial practices for the trustee's activities as a general rule. It specifies the obligation to protect the managed assets from foreseeable risks and sets a requirement accordingly, the principle of reasonable commercial practices that is higher than the general level, the generally expected standard of conduct in a given situation.

In this tripartite legal relationship (settlor - trustee - beneficiary), the trustee has the key role. It is closely linked to the fact that the trustee shall become the owner of the trust property, pursuant to section 6:310 (1) of the Civil Code. It is a targeted management of the asset since the trustee manages the assets entrusted to them in their own name but on the beneficiary's (beneficiaries') behalf. ${ }^{11}$ It also implies that the trustee shall have the right of disposal over the managed assets according to the conditions and within the limits set out in the contract [section 6:318 (2) of the Civil Code]. This dual ownership structure, the separation of the owner in economic terms and the owner in legal terms, has not been scrutinized more thoroughly in the Hungarian legal literature.

It can be generally stated that in the recent few years there has been a lack of focus to the changes of ownership concerning the fiduciary asset management relationship in the Hungarian legal literature. ${ }^{12}$ The other issue, besides quasi dual ownership, to be scrutinized deeper is the extent to which fiduciary asset management breaks through the boundaries of

9 However, it is disputed whether the assets managed by the trustee shall be included in the settlor's estate. In our view it shall be not because the title over it has been transferred by the settlor to the trustee. The estate includes the assets which the testator is entitled to upon his death. Anything that is not the part of the deceased's assets upon his death shall not be included in his estate. The assets managed by the trustee shall not be included in the part of the deceased settlor's assets (or at least in legal terms) therefore it shall not be included in his estate. A similar view is shared in: B. Szabó et al. (2014) 127.

${ }^{10}$ The principle of reasonable commercial practices is a higher standard than the principle of the generally expected stander of conduct in a given situation which is governed by section 1:4. $\S$ (1) of the Civil Code as a general principle. The principle of reasonable commercial practices arises in the Civil Code three times: when selling the pledged property by the lien holder [section 5:133 of the Civil Code], in relation to the rules of the contract of carriage [section 6:264], and in respect of the fiduciary asset management [section 6:317. § (2)].

11 This is an important difference from the personal service because the agent shall act on the principal's behalf. If the asset management was undertaken in a traditional agency contract, the agent (as the trustee) should act on the settlor's behalf and according to his instructions. However, section 6:316 of the Civil Code specifies as a cogent provision that the settlor and the beneficiary may not give instructions to the trustee; any clause to the contrary shall be null and void.

12 Menyhárd also discusses about the property law aspects of the fiduciary asset management. Menyhárd (2015) 226-43. 
'the numerus clausus of rights in rem' principle. Another issue is that to what extent fiduciary asset management can be regarded as a transaction of fiduciary nature.

However, it is undisputed that fiduciary asset management is an independent legal title for the transferring ownership, ${ }^{13}$ which means, among others, that it is an individual legal title in the real estate register and the register of companies. ${ }^{14}$ The fiduciary asset management, more precisely the settling assets does not only cover the transfer of possession but the transfer of ownership as well. Therefore, the Hungarian Civil Code presumes that the trustee acquires ownership over the trust property, and acquires the rights and receivables related to the property. ${ }^{15}$

The settlor is also vested with certain rights by the Act as a matter of course. The role of the settlor is the most significant when establishing the legal relationship before the transfer of assets. In this period, the settlor has the extensive right of disposal which enables them to form the content of the legal relationship in accordance with their own interests. However, the settlor has several rights even after establishing the legal relationship:

- they may come forward to request the separation of the trust property [section 6:313 (2) of the Civil Code];

- they may inspect the trustee's activities concerning the asset management [section 6:315 of the Civil Code];

- if the trustee breaches the fiduciary asset management contract and transfers without authorisation any assets that belongs to the property trust to a third party, the settlor shall have the right to claim that the asset be returned to the trust property, if the third party did not act in good faith or there was no pecuniary interest [section 6:318 (3) of the Civil Code];

- the principal may terminate unilaterally the fiduciary asset management contract concluded for an indefinite period [section 6:326 (1) e) of the Civil Code]. ${ }^{16}$

The Civil Code also provides some rights to the beneficiary. The fiduciary asset management contract was established in their favour and the asset management is carried out in their favour, therefore it is justified to provide them the possibility to take actions to protect the trust property. Thus the Act provides the beneficiary, in addition to the settlor, the right to separate and to recover the trust property. In addition, the beneficiary shall also be entitled to supervise the trustee. ${ }^{17}$

It is important to highlight that the nature of the right to recover the assets provided in section 6:318 (3) is not clear since it has contract law and property law characteristics too. ${ }^{18}$

Also the operation of this new legal institution requires more than the flexible and high quality civil law regulation of the Civil Code. The provisions of Act XV of 2014 on trustees and the rules on their activities, which mainly have administrative law features, are also

13 Menyhárd (2017) 37.

14 The fiduciary asset management shall only be recorded in the register of companies if a partnership share is also attached to the principal's assets.

15 B. Szabó et al. (2014) 105-06.

16 This new rule was stipulated by Act LXI of 2017 on the amendment of certain acts for the purpose of enhancing the legal competitiveness of the business environment (hereinafter the Competitiveness Act) which Act also amended the Civil Code.

17 Neither the beneficiary nor the principal shall have the right to give instructions so none of them may give instructions to the trustee.

18 Accordingly, see B. Szabó et al. (2014) 237. 
significant. In the future, favourable taxation rules can also contribute to make this construction even more attractive. ${ }^{19}$

Repealing section 132/A (3) to (5) ${ }^{20}$ of Act LIII of 1994 on judicial enforcement (hereinafter the Judicial Enforcement Act) in 2017 made the legal regulation of the fiduciary asset management even more favourable. ${ }^{21}$ These contradictory provisions have been strictly criticised in the legal literature. ${ }^{22}$ Their repeal largely strengthened the function of the fiduciary asset management to protect assets.

\section{ISSUES ARISEN IN PRACTICE}

For three years following the entry into force of the Civil Code, more issues arouse in relation to the application of the fiduciary asset management in practice which could not be clearly addressed on the basis of the original wording of the provisions of the Civil Code. Among them, the two most important issues were:

a) Can the parties exclude the settlor's right to unilaterally terminate the contract in the fiduciary asset management contract that is concluded for an indefinite period?

b) The clarification of the relationship between the trust property and the claims for a compulsory share, in particular as to whether the trust property is to be included in the base of the compulsory share?

The first issue concerning the question whether the fiduciary asset management contract (legal relationship) can be unilaterally terminated by the settlor. The original text of the Civil Code made it clear that the trustee may unilaterally terminate the fiduciary asset management. In this case, pursuant to section 6:326 (1) b) the fiduciary asset management shall terminate after three months following the unilateral termination. However, in accordance with subsection (2) in the case of unilateral termination, the trustee is obliged to act, taking the interests of the beneficiary into account. Though it was not clear whether the principal was also entitled to the right to unilaterally terminate the contract.

19 In respect of the taxation rules concerning the disposition over assets, see B. Szabó et al. (2014) 81, 134-53.

20 Judicial Enforcement Act section 132/A (3)

In the judicial enforcement procedure initiated against the debtor being the settlor - in accordance with section (4) - such assets or any portion thereof shall serve as the funds to cover the claim which are due to the settlor or the holder of the right to release in the event of the termination of the settlor's legal relationship of fiduciary asset management. The judgement creditor may terminate the fiduciary asset management contract according to section (4) and as a result the claim may be collected from the portion of assets to be released to the settlor or his successor.

Judicial Enforcement Act, section 132/A (4)

If the debtor or the holder of the right to release had a claim for any assets or portion thereof in the event of the termination of the fiduciary asset management and the claim is not fully covered by the debtor's other assets or it may be satisfied only after an unreasonable long period of time, the executor shall advise the judgement creditor that he may terminate the contract giving a reasonable period of notice. If the judgement creditor has delivered his statement of termination to the executor, the executor shall send it to the trustee and shall seize the debtor's claim outstanding against the trustee due to the termination of the legal relationship of fiduciary asset management (sections 110 to 113).

21 Repealed by section 11 c) of the Competitiveness Act. Repealed since 23 June 2017.

22 B. Szabó et al. (2014) 241-43 and Menyhárd (2017) 41. 
The other group of the issues concerned the relationship between fiduciary asset management and the mandatory provisions of the law of succession. First of all, it made necessary to clarify the relationship between the claim for a compulsory share and trust property under fiduciary asset management.

For the purposes of avoiding subsequent uncertainties in the application of law, the Competitiveness Act, Act LXI of 2017 on the amendment of certain acts for the purpose of enhancing the legal competitiveness of the business environment, aimed to address these issues in $2017 .^{23}$

\section{THE UNILATERAL TERMINATION OF FIDUCIARY ASSET MANAGEMENT BY THE SETTLOR}

More issues arouse in relation to the unilateral termination of the fiduciary asset management contract (legal relationship) by the settlor:

- Can the principal unilaterally terminate the fiduciary asset management?

- If so, can the right of unilateral termination be excluded in the contract?

- Is the settlor's successor entitled to the right of unilateral termination?

- Can the original settlor exclude or limit the right of unilateral termination for their own legal successor?

A need emerged in jurisprudence for the Civil Code to settle these issues and regulate the matter of legal succession of the settlor. The issue of legal succession is relevant especially if a natural person settlor designates their legal successor who is not their heir so the rules of succession should not apply.

According to the majority view, it was possible to unilaterally terminate the fiduciary asset management contract by the settlor even pursuant to the original wording of the provisions of the Civil Code. ${ }^{24}$ However, it seemed to be reasonable to expressly state it including the possibility of entitlement of the parties to exclude the right of unilateral termination in fiduciary asset management contracts concluded for an indefinite period.

The amendment set it as an optional rule (Section 24 of the Competitiveness Act). Therefore, the amended section 6:326 (1) of the Civil Code stipulates that the fiduciary asset management shall terminate if the settlor unilaterally terminates the contract concluded for an indefinite period, unless otherwise provided in the contract. This new provision made it clear that the settlor is also entitled to unilaterally terminate the fiduciary asset management contract concluded for an indefinite period.

However, the parties may also agree otherwise in the contract that is they may exclude or limit the settlor's right of unilateral termination. If the parties exclude the right of unilateral termination, the fiduciary asset management shall be deemed irrevocable. Pursuant to the mandatory rule set out in section 6:326 (3) of the Civil Code, the fiduciary

23 Announced in the Hungarian Gazette, Volume No. 85, 2017 (8 June 2017). Most of the provisions of the Act entered into force on the 15th days following its date of announcement (accordingly the date of entry into force: 23 June 2017). Section 46 of Competitiveness Act.

24 The unilateral termination of the fiduciary asset management contract by the settlor may also be concluded from section 6:213 (3) of the Civil Code. Pursuant to this provision, unless otherwise provided in this Act, a contract concluded for a definite period, setting up a long-term relationship may be unilaterally terminated by either party giving a reasonable period of notice. The exclusion of the right of unilateral terminate shall be null and void. 
asset management contract concluded for an indefinite period which cannot be terminated by the settlor should also be terminated after fifty years.

This new optional rule created a clear situation by ensuring the stability of the fiduciary asset management contract and by not violating the flexibility of the construction.

\section{FIDUCIARY ASSET MANAGEMENT AND CLAIM FOR A COMPULSORY SHARE}

Other issues to be addressed concerned the relationship between the fiduciary asset management and the mandatory provisions of the law of succession. First of all, it required to clarify whether the trust property should be added to the base of the compulsory share. Pursuant to section 7:75 of the Civil Code, the descendant, spouse, and parent of the settlor being the testator shall be entitled to a compulsory share if such person is, at the time of the opening of the succession, the deceased's legal heir or would be deceased's legal heir in the absence of a testamentary disposition.

The question regarding on what grounds the person entitled to a compulsory share may lay claims against the trust property if they are also the beneficiary of the fiduciary asset management after the death of the natural person settlor had to be answered.

When addressing the succession law issue, it should be presumed that fiduciary asset management cannot serve as means for circumventing the cogent provisions of the law of succession.

Therefore, in the Civil Code's Book on Succession, it had to be made clear that the value of the assets given by the deceased in fiduciary asset management must be included in the base of compulsory share. This was done by the amendment of section 7:80 (1) of the Civil Code. The amended wording of the provision states that the base of the compulsory share shall be the net value of the estate and the net value at the time of benefiting of the donations granted inter vivos by the deceased to any person, including the value of the property entrusted to fiduciary asset management by the deceased. Therefore, in accordance with the amended wording of the provision, the assets property entrusted to fiduciary asset management shall be regarded as donation for this purpose. However, it also implies that section 7:81 (1) a) shall also apply to the assets entrusted to fiduciary asset management. According to this provision, the value of donations granted by the deceased to others more than ten years prior to their death shall not be included in the base of a compulsory share.

It means that the value of assets entrusted to fiduciary asset management less than ten years prior to the settlor's death shall be included in the base of compulsory share. However, the value of assets entrusted to fiduciary asset management more than ten years prior to the settlor's death shall not be included in the basis of compulsory share. ${ }^{25}$

These amendments also clarified that it is the trustee against whom the person entitled to a compulsory share may make their claim. Previously, there was a view stating that the

25 The compulsory share is that the descendants, spouse, and parents of a testator shall be entitled to under Section 7:75 of the Civil Code if such person is a legal heir of the testator or would be one in the absence of a testamentary disposition at the time of the opening of the succession. Under Section 7:80 (1) of the Civil Code the basis of a compulsory share of inheritance is the net value of an estate, and the net value, at the time of advancement, of the advancement granted by the testator inter vivos, including the value of assets entrusted to a fiduciary under fiduciary asset management (hereinafter referred to as 'advancement'). 
person entitled to a compulsory share should lay their claim against the beneficiary. ${ }^{26}$ But since the trustee is the owner of the assets, it is justified in every aspect that the person entitled to a compulsory share shall lay a claim against the trustee and they should be obliged to release the assets.

The amendment intended to clarify the relationship between the freedom of contract and the mandatory provisions on compulsory share. In this regard, the legislature made it clear that the mandatory provisions of the law of succession limit the principal's right of disposal.

\section{OTHER SUCCESSION LAW ISSUES}

Another amendment concerned section 7:96 (5) of the Civil Code. Pursuant to the amended wording of the provision, regarding a fiduciary asset management relationship established under a will, the trustee shall bear liability for estate debts with the trust property as if they were given a specific item or property.

Another amendment in succession law concerned the fiduciary asset management relationship established under a will. It was the amendment of section 6:329 (2) of the Civil Code. Pursuant to the amended wording of the provision, the fiduciary asset management relationship established under a will shall enter into existence upon the trustee's acceptance of the appointment under the conditions set out in the will with retroactive effect to the time of the settlor's death.

Therefore, the amended wording of the provision specifies that:

- regarding a fiduciary asset management relationship established under a will, the fiduciary should be appointed in the will

- the appointment should be accepted by the trustee;

- the appointment may only be accepted under the conditions set out in the will

- the fiduciary asset management relationship established under a will should take effect upon the trustee's acceptance of the appointment with retroactive effect to the time of the trustee's death.

Finally, there is another issue in relation to succession law; if the beneficiary is also entitled to a compulsory share, can they lay a claim against the trustee on legal grounds under contract law and under law of succession as well? Another issue is that if the beneficiary could lay a claim on both grounds stated above, can he choose which ground that they may lay a claim which results in more? In this relation, the issue is revealed that whether the settlor is entitled to determine that the person who lay any claim, thus a claim for compulsory share, against the trust property should lose their beneficiary status. For the purpose of enhancing the flexibility of the construction, section 22 of the Competitiveness Act added a new optional provision to section 6:311 of the Civil Code. In accordance with the new subsection (5) of Section 6:311 of the Civil Code, the beneficiary status shall cease to exist if the beneficiary lays a claim against the trust property under a legal title other than those set out in the contract. Therefore, the settlor's right of disposition has been extended and completed with the possibility of disqualifying from the beneficiary status those who lay a claim against the trust property upon other grounds, for example for a compulsory share.

The provision for excluding the enforcement of a claim on two different grounds is relevant if there are more than one beneficiary to the trust property. In this case, despite the 
original intent of the settlor the beneficiary who lays claims upon more grounds may be placed at a more favourable position than the other beneficiaries. ${ }^{27}$

\section{SUCCESSION IN THE POSITION OF THE SETTLOR}

There was a demand for the Civil Code to regulate legal succession in the position of the settlor. It was a question whether legal succession in the position of the settlor is possible, whether the heir of the natural person shall automatically enter in the legal relationship as the settlor's legal successor by virtue of law.

It is important to note that the question whether positions in contract can be the subject of succession may arise not only in relation to the fiduciary asset management but also to any other contract. Therefore, the legislator did not intend to make an amendment which would have regulated the possibility of succession in the position of a party of a contract only in case of the fiduciary asset management. It could have entailed such a conclusion that this possibility does not apply to any other type of contract.

Thus the amendment only enabled the settlor to appoint the person who should be entitled to exercise his rights and to fulfil their obligations in the event of their death or dissolution. In Anglo-Saxon law, the person appointed to exercise the settlor's rights is called the 'protector' with the essential difference that the settlor may appoint a protector not only for the event of their death and dissolution without succession. ${ }^{28}$

Thus, the new subsection (4) of section 6:325 of the Civil Code states that for the event of the settlor's death or dissolution without succession, the settlor may appoint a person in the contract to exercise their rights and to fulfil their obligations. Upon accepting the appointment in a statement addressed to the trustee, the person appointed shall have the trustee's rights and obligations within the limits set out in the contract.

Therefore, the settlor also has the right to restrict the right of the person appointed by them. For example, they may exclude the unilateral termination of the asset management contract by the appointed person.

Succession shall apply when the natural person settlor does not appoint a person to exercise their rights and to fulfil their obligations in the event of their death.

It can also be found that such a recent academic opinion that this appointment in new subsection (4) of section 6:325 of the Civil Code should be regarded as a testamentary disposition. In accordance with this opinion, there is a contradiction between section 6:325 (4) of the Civil Code and the succession law provisions. The obligatory form of the statement as a testamentary disposition or the date and conditions of the transfer of the settlor's rights and obligations upon the legal successor is not clear. ${ }^{29}$

However, in the Author's view, the appointment specified in the new wording of the provision may not be regarded as a testamentary disposition. Pursuant to section 7:10 of the Civil Code, testators shall be entitled to freely arrange for their property or a part thereof, in a testamentary disposition upon their deaths. Accordingly, the testamentary disposition shall always concern the testator's property. The testator shall dispose of their property or a part thereof. However, when the settlor appoints a person to exercise

27 Tökey (2018) 319.

${ }^{28}$ However, interpretation issues arise also in respect of the legal status of protector, first of all the issue to what extent the appointed protector shall be entitled to pursue the settlor activities after his death or dissolution without succession. See B. Szabó et al. (2014) 113.

29 Tökey (2018) 320. 
their rights and to fulfil their obligations upon their death, the settlor does not arrange for their property. In this case, it is not an arrangement for the testator's property therefore this kind of appointment may not be regarded as a testamentary disposition.

It is also a disputed view that, in accordance with the principle of ipso iure succession at the time of the settlor's death, the successor - without any legal statement - automatically replaces the settlor and the statement on accepting the appointment addressed to the settlor has only have declarative effect. ${ }^{30}$ As a matter of course, the person appointed replaces the settlor at the time of the settlor death. However, they shall accept the appointment by a legal statement that is addressed to the settlor. The situation is similar to fiduciary asset management relationship established under a will. In this respect section 6:329 (2) of the Civil Code clearly states that the fiduciary asset management relationship established under a will shall take effect upon the trustee's acceptance of the appointment under the conditions set out in the will with retroactive effect to the time of the trustee's death. By analogy the person appointed by the settlor shall also be entitled to exercise the settlor rights and shall be obliged to fulfil the settlor's obligations upon accepting the appointment with retroactive effect to the time of the settlor's death. Therefore, there is no uncertainty about the date and conditions of the transfer of the settlor's rights upon the person appointed.

\section{CONCLUSIONS}

The amendment of the provisions of the Civil Code concerning fiduciary asset management mainly intended to clarify the issues recently arisen causing interpretation problems. These amendments intended to strengthen the function of this legal institution to protect assets, which is a priority aspect especially for foreign settlors. The protection of assets is mostly enhanced by settling the issue of unilateral termination and repealing section 132/A (3) to (5) of the Judicial Enforcement Act. By regulating the unilateral termination of the contract, it became clean-cut that if the parties excluded the settlor's right of unilateral termination for a fiduciary asset management contract concluded for an indefinite period, the fiduciary asset management shall be deemed irrevocable.

In addition to the provisions of the Civil Code concerning fiduciary asset management, Act XV of 2014 on trustees and the rules on their activity also required a comprehensive amendment. In this context, the group of those authorised to carry out asset management was extended, and a distinction between fiduciary asset management and the investment service activity was made. However, it was important to maintain the state control over this activity. This control is mainly needed for fiduciary asset management activities for financial gain but the state may not waive its right to a minimum control over temporary asset management. It is supervision in the tradition sense but an official control which may address in a due time possible misuses. This official control is carried out by the Hungarian National Bank.

The aim of the legislature was clearly to increase the interest of Hungarian and foreign settlors by a functioning fiduciary asset management construction. Regarding the relevant Hungarian rules, it should be noted that fiduciary asset management may have a significant role in family asset planning in the future because more and more family enterprises are 
managed under fiduciary asset management. This legal institution may also play the role of a transfer of assets between generations. ${ }^{31}$

The interest of the potential foreign principals toward Hungarian fiduciary asset management may be based on the high level of protection of assets primarily in the Hungarian legal regulation. It is also strengthened by not sharing the exercising of ownership rights under the Civil Code (the trustee is the owner), moreover the tax regulations are favourable, and that this legal institution cannot be used for concealing assets because there is a well-established case law concerning restricting transactions for concealing assets.

The enterprises pursuing fiduciary asset management for financial gain requires extensive human resources. The asset management activity requires not only qualified lawyers and accountants who speak several languages but also financial and controller staff with investment experiences. These qualified professionals typically earn a high income so the employer's contributions paid after them are also high. The more efficient these enterprises are the more qualified professionals they will employ and thus more taxes (usually personal income tax and value added tax) and other rates they will pay in Hungary. It is also an essential aspect that these enterprises use the Hungarian banking system during their asset management activity and they invest a significant part of the assets managed into Hungarian real estate and Hungarian state securities.

\section{LITERATURE}

B. Szabó, Gábor, Illés, István, Kolozs, Borbála, Menyhei, Ákos and Sándor, István, A bizalmi vagyonkezelés (The fiduciary asset management) (HVG-ORAC 2014).

Csehi, Zoltán, 'A vagyonkezelés formái és intézményei a magyar magánjogban' (The Forms and Institutions of Asset Management in the Hungarian Law) in Kisfaludi, András (ed), Tanulmányok a bizalmi vagyonkezelés jogi szabályozásának elméleti alapjairól (ELTE Eötvös Kiadó 2015a) 95-132.

Csehi, Zoltán, ‘A bizalmi vagyonkezelés történelmi előzményei’ (The Historical Roots of fiduciary asset management) in Kisfaludi, András (ed), Tanulmányok a bizalmi vagyonkezelés jogi szabályozásának elméleti alapjairól (ELTE Eötvös Kiadó 2015b) 9-52.

Csizmazia, Norbert and Sándor, István, 'A bizalmi (fiduciárius) vagyonkezelés modellje és a Ptk. reformja' (The model of fiduciary asset management and the reform of the Civil Code) (2002) 4 Polgári Jogi Kodifikáció, 21-22.

Menyhárd, Attila, ‘A bizalmi vagyonkezelési szerződés jogi szabályozásának aktuális kérdései' (The current issues of the legal regulation concerning the fiduciary asset management contract) (2017) 1 Fontes Iuris, 37-43.

Menyhárd, Attila, 'A bizalmi vagyonkezelés a magyar polgári jogban' (The fiduciary asset management in the Hungarian civil law) in Kisfaludi, András (eds), Tanulmányok a bizalmi vagyonkezelés jogi szabályozásának elméleti alapjairól (ELTE Eötvös Kiadó 2015), 226-43.

Tőkey, Balázs, 'Új szerződéstípusok a Polgári Törvénykönyvben' (New types of contracts in the Civil Code) in Vékás, Lajos (ed), Fejezetek a Polgári Törvénykönyv keletkezéstörténetéböl (Magyar Közlöny Lap- és Könyvkiadó 2018.) 283-325.

31 See also: B. Szabó et al. (2014) 61-70. 